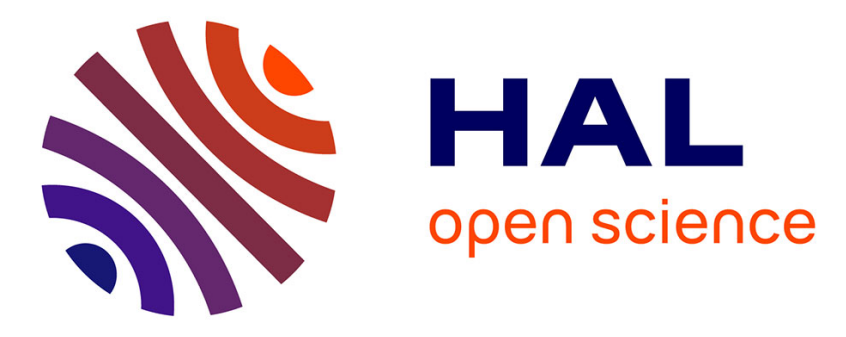

\title{
Spatial variation in public attitudes towards brown bears in the French Pyrenees
}

Blaise Piédallu, Pierre-Yves Quenette, Coralie Mounet, Nicolas Lescureux, Maylis Borelli-Massines, Etienne Dubarry, Jean-Jacques Camarra, Olivier Gimenez

\section{To cite this version:}

Blaise Piédallu, Pierre-Yves Quenette, Coralie Mounet, Nicolas Lescureux, Maylis Borelli-Massines, et al.. Spatial variation in public attitudes towards brown bears in the French Pyrenees. Biological Conservation, 2016, 197, pp.90-97. 10.1016/j.biocon.2016.02.027 . halshs-01629063

\section{HAL Id: halshs-01629063 \\ https://shs.hal.science/halshs-01629063}

Submitted on 7 Sep 2020

HAL is a multi-disciplinary open access archive for the deposit and dissemination of scientific research documents, whether they are published or not. The documents may come from teaching and research institutions in France or abroad, or from public or private research centers.
L'archive ouverte pluridisciplinaire HAL, est destinée au dépôt et à la diffusion de documents scientifiques de niveau recherche, publiés ou non, émanant des établissements d'enseignement et de recherche français ou étrangers, des laboratoires publics ou privés. 


\title{
Spatial variation in public attitudes towards brown bears in the French Pyrenees
}

\author{
Blaise Piédallu ${ }^{\mathrm{a}, *}$, Pierre-Yves Quenette ${ }^{\mathrm{b}}$, Coralie Mounet ${ }^{\mathrm{c}}$, Nicolas Lescureux ${ }^{\mathrm{a}}$, Maylis Borelli-Massines ${ }^{\mathrm{b}, \mathrm{c}}$, \\ Etienne Dubarry ${ }^{\mathrm{b}}$, Jean-Jacques Camarra ${ }^{\mathrm{b}}$, Olivier Gimenez ${ }^{\mathrm{a}}$ \\ a CEFE UMR 5175, CNRS, Université de Montpellier, Université Paul-Valéry Montpellier, EPHE, 1919 Route de Mende, 34293 Montpellier Cedex 5, France \\ b Office National de la Chasse et de la Faune Sauvage, CNERA PAD-Equipe Ours, Impasse de la Chapelle, 31800 Villeneuve-de-Rivière, France \\ ' UMR Pacte, Institut d'études politiques, BP 48, 38040 Grenoble Cedex 9, France
}

\section{A R T I C L E I N F O}

\section{Article history:}

Received 1 August 2015

Received in revised form 18 February 2016

Accepted 23 February 2016

Available online $\mathrm{xxxx}$

\section{Keywords:}

Attitudes

Brown bear

Human-wildlife conflicts

Large carnivores

Sociological survey

Spatial heterogeneity

\begin{abstract}
A B S T R A C T
Human dimension is an important component of large carnivore management and conservation. Here, we focus on the human-wildlife conflict related to depredation of livestock by Pyrenean brown bears (Ursus arctos), despite the population being among the smallest in the world. Two reintroductions were performed in the past to ensure the survival of the population, yet its conservation status remains critical due to small size, heavy inbreeding and disagreements over its management. We investigated the often-neglected spatial variations in attitude towards predator presence to improve our understanding of the human dimensions surrounding this conflict. We used a questionnaire to assess the drivers explaining the attitude of the local human population $(n=577)$ of the Pyrenees towards bear presence. Our results show that spatial variables (place of birth and county of residence of the respondent) are strong predictors of attitude. The residents of two counties in particular (Haute-Garonne and Pyrénées-Atlantiques) displayed a positive attitude, while the residents of the HautesPyrénées county had the most negative attitude. People born outside of the Pyrenees also showed a more positive inclination towards bear presence than people born and raised in France's southwestern mountain range. Both these results may imply a link between the history of local communities with predator presence and their current attitude. Accounting for small-scale spatial heterogeneity in social-ecological studies of human-wildlife conflicts will prove useful to get a more accurate mapping of attitudes and inform subsequent management decisions.
\end{abstract}

(c) 2016 Elsevier Ltd. All rights reserved.

\section{Introduction}

Human dimensions play an essential role in the management and conservation of large carnivores (Treves and Karanth, 2003; Dressel et al., 2015). Focusing exclusively on the biological aspects of conservation may lead to persistent conflict (Redpath et al., 2013), marked by a lack of agreement and unilateral solutions, if any. Therefore, knowing the attitudes of local human populations is an essential step in the management of human-wildlife conflicts (Redpath et al., 2013).

The local attitudes towards wildlife populations are typically investigated using sociocultural parameters, such as gender (Bath et al., 2008; Gore and Kahler, 2012), age (Majić and Bath, 2010), scientific knowledge of the species' ecology (Kaczensky et al., 2004; Thornton and Quinn, 2009; Glikman et al., 2012), participation in activities related to wildlife (Bath et al., 2008; Majić et al., 2011; Gangaas et al., 2013) and involvement in farming/ranching (Kaczensky et al., 2004; Sponarski et al., 2013). However, the geographic location of the residence is rarely considered, except at very large spatial scales such as entire regions (Kaczensky et al., 2004; Majić and Bath, 2010) or countries (Gangaas

\footnotetext{
* Corresponding author at: Blaise Piédallu CEFE - CNRS UMR 51751919 Route de Mende 34293 Montpellier Cedex 5.

E-mail address: blaise.piedallu@cefe.cnrs.fr (B. Piédallu).
}

et al., 2013). Smaller-scale spatial variations in attitudes within rural areas remain largely unexplored (Sponarski et al., 2013) despite their potential to improve our understanding of the sociological component of human-wildlife conflict. First, working at small-scale helps circumventing the risk of flawed inference if spatial variations are ignored as it is equivalent to consider the mean value of all attitudes a statistic known to be highly sensitive to extreme values (van Belle et al., 2004) - which might lead to people holding very strong opinions in one way or another driving the population value. Second, increased spatial resolution in the assessment of attitudes allows for greater latitude through targeted conflict management and locally adapted solutions.

Here, we focused on brown bears (Ursus arctos) in the Pyrenees as a case study. Brown bear populations in Europe, like other large carnivores, exhibit a global increase in abundance and range expansion during the last twenty to thirty years (Chapron et al., 2014). However, the Pyrenean population, located on the border between Southwestern France and Northeastern Spain, remains among the smallest in Europe. After nearly going extinct in 1995 with 5 individuals remaining in two valleys of the Western Pyrenees, two reintroduction sessions with brown bears coming from Slovenia in 1996-1997 (one male, two females) and 2006 (one male, four females) led to a current population size of about 30 individuals. The reintroductions also led to the return of brown bears in geographical areas where they had disappeared for 
decades in Central Pyrenees, to form the Central-Eastern population core, while the Western population core kept declining and is currently functionally extinct with two males and no females. Based on demographic analyses, it was suggested that the Pyrenean bear population should be reinforced via reintroductions to ensure its viability (Chapron et al., 2009). The management of the population, however, is made complex by the various spatial scales involved (ranging from the country level to very small municipalities) and the different political situations and changing local actors from one area to another (Benhammou, 2007). The bulk of the bear population on the French side is located in Ariège where according to Benhammou (2007) stakeholders tend to oppose to its presence. Most reintroductions occurred in the neighboring county of Haute-Garonne in which a few local actors were advocating for an increase in the bear population. Political context combined with depredation of sheep (127 attacks and 178 animals killed in 2014, Camarra et al., 2015) and local distrust of scientific data on the Pyrenean bear hamper decision-making in bear management (Mermet and Benhammou, 2005).

In recent years, various quantitative studies of the attitudes of local populations towards bears in potentially conflictual areas have been performed in different European countries, with some results showing positive attitudes such as in Slovenia (Kaczensky et al., 2004), Italy (Glikman et al., 2012) or Romania (Dorresteijn et al., 2014), while some other results pointed to negative attitudes towards bear presence such as in Croatia (Majić et al., 2011). In France, according to Mermet (1998), the conflict surrounding bears primarily pits environmentalists willing to augment the bear population against livestock breeders viewing bears as dangerous predators - mostly upon sheep. Bears in the Pyrenees are strictly protected by the National (France, 1976, Loi No. 76-629 du 19 Juillet 1976 relative à la protection de la nature) and European (European Union, 1992, Annexes II and IV) laws, and management which includes compensation for livestock losses if signs of predation on the carcass can be attributed to the bear by an agent of the National Game and Wildlife Agency (ONCFS). Only one qualitative assessment of attitudes (conducted through interviews with selected stakeholders) towards bears in the Pyrenees was carried out almost 10 years ago (Benhammou, 2007), and described the complex politics surrounding bear presence in several distinct areas that displayed varying histories and attitudes regarding bear conservation. Quantitative studies of attitudes of local residents have yet to be performed, with the aim of encompassing a larger sample of the Pyrenean population and describing their attitudes through a statistical analysis as well as mapping of the attitudes towards bear presence.

By controlling for a large variety of variables whose effect on attitudes has previously been documented (such as age or scientific knowledge of the bear ecology), we aim to investigate spatial heterogeneity in the attitude of local populations towards bear presence in the Pyrenees. We hypothesize that the recent history of the Pyrenean areas with bear presence (since 1996 and the first reintroductions) could influence the attitudes of its residents even at a small scale, and that the place of birth could also influence the attitudes of the local populations, with people born in the Pyrenees exhibiting more reserved attitudes towards bear presence after being directly or indirectly confronted with depredation or conflicts involving bears (Ericsson and Heberlein, 2003).

\section{Methods}

\subsection{Study area}

We performed the study on the French side of the Pyrenees mountains that form the border between Southwestern France, Northeastern Spain and Andorra (Fig. 1). We considered as a target for the survey the 387 municipalities (in 6 Pyrenean counties) where bear presence had been confirmed between 2008 and 2013 by the ONCFS. These six counties are characterized by different past and present histories with bear presence. Pyrénées-Atlantiques (PA) always had bears, and the remaining five bears in 1995 lived in the valleys of Aspe and Ossau, south of Oloron-Sainte-Marie, and the valleys of Isaba (Navarre), Hecho and Anso (Aragon). One bear currently lives in this county. In contrast, in the Hautes-Pyrénées (HP), bears only returned in the 2000s, with one bear entering in 2001, another one settling in 2006 and remaining there ever since, and one female being reintroduced in 2006 and died in 2007. While most reintroductions were performed in Haute-Garonne (HG) from 1996 onwards, the bulk of the population in the Central Pyrenees currently resides in Ariège (AR). In both counties, previous bear observations were made in the 1970s. There has been on-and-off bear presence in Aude (AU) and the PyrénéesOrientales (PO) between 2000 and 2011, with the most recent observations in 2011 and 2010, respectively.

The 387 municipalities were classified by postcode, and we selected 36 of these postcodes as targets for the survey. All of the postcodes that included municipalities with permanent bear presence (tracks found in three or more years between 2008 and 2013) were included along with those with the largest number of municipalities with occasional bear presence (one or two years between 2008 and 2013). One postcode was specifically added to include the urban area of Lourdes in HP. This addition was performed because PA included an urban area in the foothills in the mountains (Oloron-Sainte-Marie), hence allowing comparison of the two Western counties because the demographic compositions of their human population samples were similar. Postcodes were split between Rural and Urban ones for AR, HG, PA and HP (Table A.1) - an urban postcode being defined as including at least one municipality with more than 2500 inhabitants according to the National Institute of Statistics and Economical Studies (INSEE). Although oversimplified, this definition of rural and urban areas ensured that both rural and urban areas were targeted during the survey, even though almost all municipalities on which signs of bear presence had been found were rural ( 375 out of $387,96.9 \%$ ).

\subsection{Sampling and data collection}

The 3000 questionnaires were split between Rural and Urban postcodes for four of the six counties (Table A.1). In total, 1200 questionnaires were sent in the Western population core area (PA, HP) and 1800 in the Central-Eastern population core area (HG, AR, AU, $\mathrm{PO}$ ) to reflect the smaller size of the Western population core. We sent more questionnaires in AR than in HG due to AR containing the largest part of the bear population, and bear presence being identified in 169 municipalities versus 48 municipalities in HG. Fewer questionnaires were sent in $\mathrm{AU}$ and $\mathrm{PO}$ that have no current bear presence.

Within these postcodes, we performed a random sampling without targeting any gender, age or social class. We used $\chi^{2}$ tests of independence to assess whether there was a bias in the return rate in some counties, or according to gender and age, by comparing our sample to the Pyrenean population (INSEE, 2014). The mail questionnaires were sent in June 2014, with answers registered until September 2014.

Besides mail questionnaires that targeted the general public, we performed interviews in order to obtain a large enough sample of livestock breeders filling in the questionnaire by traveling in the areas of interest. Even though livestock breeders were the ones that were mostly targeted, we also received answers from hunters, beekeepers, tourism professionals or other members of the public showing an interest in the questionnaire. The field survey was performed over one month in June 2014 using snowball sampling (asking each respondent for possible acquaintances that may be interested in the survey, Dillman et al., 2014) by traveling in the Pyrenees and mostly meeting local livestock breeders, along with occasional members of the general public that did not breed livestock and either showed an interest in the conflict, or whose activity could be linked to bear presence, such as tourism or hunting. 


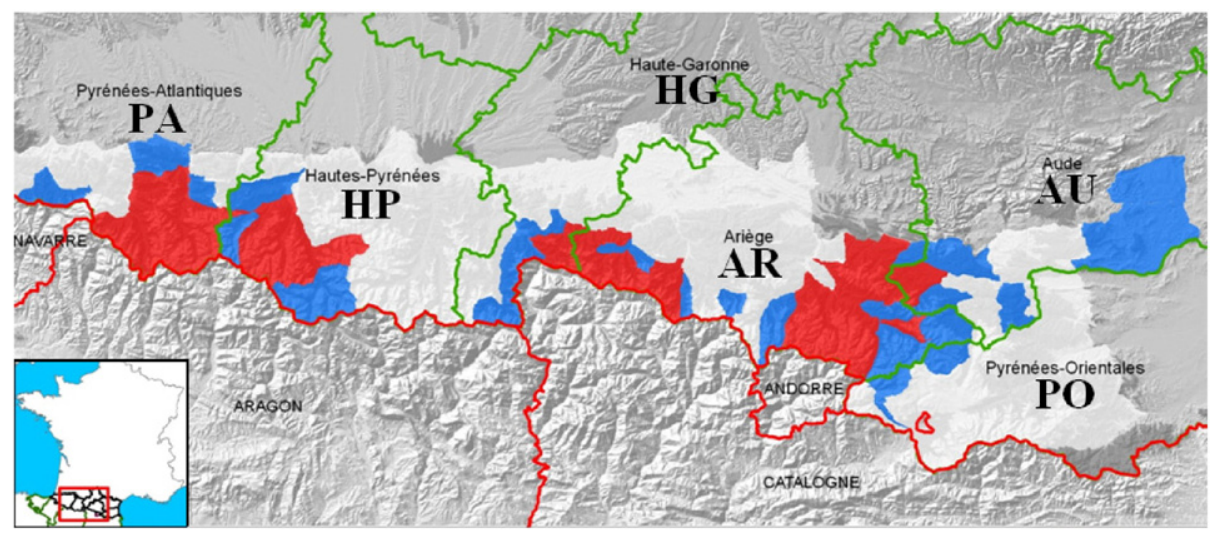

\begin{tabular}{lccccccc}
\hline County & PA & HP & HG & AR & AU & PO \\
\hline $\begin{array}{l}\text { Current } \\
\text { population } \\
\text { size }\end{array}$ & $1-2$ & $1-2 *$ & $9+*$ & $14+$ & 0 & 0 & \\
$\begin{array}{l}\text { Type of } \\
\text { presence }\end{array}$ & Continuous & Returned & Returned & Returned & Temporary & Temporary & \\
$\begin{array}{l}\text { Years of } \\
\text { presence }\end{array}$ & ?-Today & $\begin{array}{c}2001- \\
\text { Today }\end{array}$ & $\begin{array}{c}1996- \\
\text { Today }\end{array}$ & $\begin{array}{c}1996- \\
\text { Today }\end{array}$ & $1999-2011$ & $1999-2010$ & TOTAL \\
\hline $\begin{array}{l}\text { Questionnaires } \\
\text { sent }\end{array}$ & 600 & 600 & 450 & 1050 & 245 & 52 & 3000 \\
$\begin{array}{l}\text { Questionnaires } \\
\text { fully returned }\end{array}$ & 89 & 101 & $\begin{array}{c}84 \\
(14.8 \%)\end{array}$ & $\begin{array}{c}175 \\
(16.8 \%)\end{array}$ & $\begin{array}{c}29 \\
(18.7 \%)\end{array}$ & $\begin{array}{c}8 \\
(11.7 \%)\end{array}$ & $\begin{array}{c}(15.4 \%) \\
(16.2 \%)\end{array}$ \\
\hline
\end{tabular}

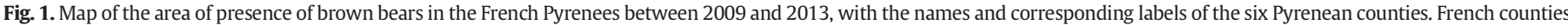

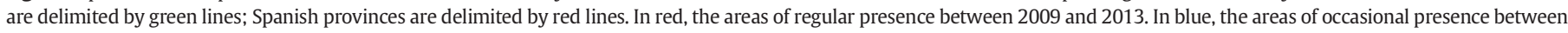

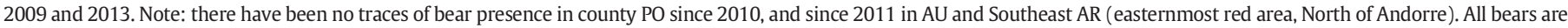

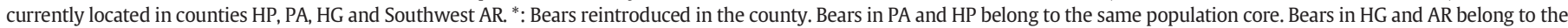
same population core. The return rates of the questionnaires are also given for every county (more details in Table A.1)

\subsection{Questionnaire design}

To design the questionnaire, we followed Majić and Bath (2010) who studied attitudes towards wolf (Canis lupus) presence in Croatia. We divided the questionnaire into three main parts: (a) the opinion of the respondent on brown bear presence in the Pyrenees in general (b) the opinion of the respondent regarding various propositions related to brown bear presence in the Pyrenees (conservation and management, hunting, livestock breeding, tourism, Table 1) and (c) social indicators concerning the respondent along with a short quiz aiming at estimating scientific knowledge on brown bear ecology in the Pyrenees, and information on possible previous encounters with brown bears. The first part included four questions measured on a five-level Likert scale ranging from "Very unfavorable" to "Very favorable". The second part included thirty-two propositions measured on a sevenlevel Likert scale ranging from "Strongly disagree" to "Strongly agree". The knowledge quiz included five different questions regarding bear ecology or biology, which were either multiple-choices or required to write the answer on a horizontal scaled bar. For each question, the respondent was given 2,1 or 0 points depending on the correctness of the answer, leading to a grade ranging from 0 to 10 out of 10 points (Appendix B).

\subsection{Statistical analyses}

While the first part of the questionnaire (opinion of the respondent on bear presence in general) was not divided due to the small number of total items (4), the second part was split into four, each section corresponding to a different theme related to bear presence in the Pyrenees: (i) bear conservation and management, (ii) bear influence on hunting, (iii) bear influence on pastoralism, and (iv) bear influence on tourism. We performed five Principal Component Analyses (PCA, one for each of the sections of the questionnaire, see Table 1 ) to handle the correlations between questions, and summarize the multifactorial signal (the number of questions per section) in a few principal components that would explain most of the variation ( $70 \%$ at least of the total explained variance), and have a strong correlation $(>|0.65|)$ to at least one item of the questionnaire. We then performed multiple linear regressions on all the relevant axes to analyze how the sociodemographic variables (Table A.2) influenced the attitude of respondents. Based on existing literature, we expected the variables "age" (Majić, 2007) or "scientific knowledge of bear ecology" (Glikman et al., 2012) to significantly influence the attitude, while "gender" should not, because it has been associated with fear instead of attitude towards large predators (Majić, 2007; Majić and Bath, 2010). To determine which combination of variables was best supported by the data, we used a stepwise procedure using the Akaike Information Criterion (AIC; Burnham and Anderson, 2002). Using results obtained through semi-structured interviews with local stakeholders in AR and HG (Borelli-Massines unpublished data), we also investigated relevant interactions between variables (Table A.2). The partial $\eta^{2}$ (Cohen, 1973) was used in every model to quantify how much of the total variance was explained by each variable or interaction of variables. All analyses were performed using version 3.0.1 of program R ( $\mathrm{R}$ Core Team, 2013).

\section{Results}

\subsection{Return rate}

Out of the 3000 questionnaires that were sent, 533 were returned (17.8\%). After eliminating the incomplete ones, we got a total of 486 answers, leading to an average return rate of $16.2 \%$. There was no bias in the return rates, complete return rates or in efficiency (complete returns/total returns) with respect to the county the questionnaire was sent in (Table A.1). 
Table 1

Questionnaire items (see Appendix B) summarized in a single table. The first 4 items (pres1 to pres4) were questions: lower values pointed towards a negative attitude of the respondent towards bears and higher values pointed towards a positive attitude towards bears. The other 28 items were sentences: the more the respondent disagreed with the proposition, the lower the values, the more the respondent agreed with the proposition, the higher the values.

\begin{tabular}{|c|c|c|}
\hline Notation & Item summary & $\begin{array}{l}\text { Additional } \\
\text { information }\end{array}$ \\
\hline pres1 & \multirow[t]{4}{*}{ Feelings towards various questions } & Bears in France \\
\hline pres2 & & Bear presence \\
\hline pres3 & & Bear conservation \\
\hline pres4 & & Bear reintroduction \\
\hline cons1 & \multirow{4}{*}{$\begin{array}{l}\text { Bear presence is important for future } \\
\text { generations... }\end{array}$} & ...in all the Pyrenees \\
\hline cons2 & & $\begin{array}{l}\text {...in the Western } \\
\text { Pyrenees }\end{array}$ \\
\hline cons3 & & ...in the \\
\hline & & $\begin{array}{l}\text { Central-Eastern } \\
\text { Pyrenees }\end{array}$ \\
\hline cons4 & $\begin{array}{l}\text { Bear presence is important because they always } \\
\text { were here }\end{array}$ & \\
\hline cons5 & $\begin{array}{l}\text { Abundant bear presence is important for future } \\
\text { generations }\end{array}$ & \\
\hline cons6 & \multirow[t]{3}{*}{$\begin{array}{l}\text { Importance of bear presence whether I see it or } \\
\text { not... }\end{array}$} & $\begin{array}{l}\text {...in the Western } \\
\text { Pyrenees (PA, HP) }\end{array}$ \\
\hline cons7 & & $\begin{array}{l}\ldots \text { in the Central } \\
\text { Pyrenees (HG, AR) }\end{array}$ \\
\hline cons8 & & $\begin{array}{l}\text {...in the Eastern } \\
\text { Pyrenees (AU, PO) }\end{array}$ \\
\hline cons9 & $\begin{array}{l}\text { Bear presence in the Pyrenees is useless because } \\
\text { there are bears elsewhere in Europe }\end{array}$ & \\
\hline cons10 & \multirow{5}{*}{$\begin{array}{l}\text { Views on bear status, from most favorable to less } \\
\text { favorable for bears }\end{array}$} & Complete protection \\
\hline cons11 & & $\begin{array}{l}\text { Relocation of bears } \\
\text { causing trouble }\end{array}$ \\
\hline cons12 & & $\begin{array}{l}\text { Hunting bears } \\
\text { causing trouble }\end{array}$ \\
\hline cons13 & & Hunting bears \\
\hline cons14 & & $\begin{array}{l}\text { Treating bears like } \\
\text { pests }\end{array}$ \\
\hline cons15 & $\begin{array}{l}\text { Bear elimination in the previous generations } \\
\text { should be pursued }\end{array}$ & \\
\hline hunt1 & $\begin{array}{l}\text { Bear attacks on humans are commonplace when } \\
\text { bears live close to humans }\end{array}$ & \\
\hline hunt2 & \multirow[t]{2}{*}{ Negative bear presence impact on... } & ...small game \\
\hline hunt3 & & ...large game \\
\hline hunt4 & $\begin{array}{l}\text { Hunting should be permitted near female with } \\
\text { cubs territory }\end{array}$ & \\
\hline hunt5 & $\begin{array}{l}\text { Bears have a positive regulating effect on game } \\
\text { population }\end{array}$ & \\
\hline hunt6 & Bears disturb hunters & \\
\hline pasto1 & \multirow[t]{3}{*}{ Bears cause important damage on... } & ...cows and horses \\
\hline pasto2 & & ...sheeps and goats \\
\hline pasto3 & & ...bee hives \\
\hline pasto4 & $\begin{array}{l}\text { Whenever available, livestock is a bear's primary } \\
\text { food source }\end{array}$ & \\
\hline pasto5 & \multirow[t]{3}{*}{ Priority between bear presence and pastoralism } & $\begin{array}{l}\text { Pastoralism }>\text { Bear } \\
\text { presence }\end{array}$ \\
\hline pasto6 & & $\begin{array}{l}\text { Pastoralism }<\text { Bear } \\
\text { presence }\end{array}$ \\
\hline pasto7 & & $\begin{array}{l}\text { Pastoralism }=\text { Bear } \\
\text { presence }\end{array}$ \\
\hline tour1 & \multirow[t]{2}{*}{ Bear effect on hikers } & Draws them \\
\hline tour2 & & Makes them flee \\
\hline tour3 & \multirow[t]{2}{*}{ Bear effect on tourists } & Draws them \\
\hline tour4 & & Makes them flee \\
\hline
\end{tabular}

\subsection{Survey sample}

The questionnaire was answered in full by 577 individuals ( 486 through mails, 91 through interviews). To describe the sample, we first assessed the distribution of the various variables. There was a bias towards male respondents $\left(\mathrm{M}=327, \mathrm{~F}=250, \chi^{2}=10.28, \mathrm{df}=1\right.$, $p<<0.01$ ). The respondents were on average 56 years old (54 for females, 59 for males). We found some bias in the age classes of respondents compared to census data on the Pyrenean population $\left(\chi^{2}=82.42\right.$, $\mathrm{df}=7, p<<0.01)$ : an under-representation of people under 30 (Dillman et al., 2014) as well as an over-representation of people between 50 and 69 years old. "Highest obtained diploma" showed a clear difference between male and female respondents in one particular class: there was a far bigger proportion of males with a professional certificate (obtained two years before the Baccalauréat, the French final school diploma, $36.4 \%$ ) than there were in females (24.0\%). We could not test whether our sample matched the diploma level of the population of the Pyrenees due to a lack of information. There were no significant differences between the respondents of the mail and field surveys for all of these variables.

Out of the 577 respondents, 538 were primary residents of the Pyrenees (residents that live most of the time in the Pyrenees, 93.2\%), and 39 were secondary residents (owned a property in the Pyrenees yet primarily lived outside of it, 6.8\%). We found that 312 residents were born in one of the six Pyrenean counties (54.1\%) while 265 were born elsewhere in France or in a foreign country (45.9\%). There is no known data to verify if this sample was representative of the Pyrenean population. 436 residents lived in rural townships (75.6\%), while 141 lived in urban townships (24.4\%). 105 respondents were livestock breeders ( $18.2 \%$ of the sample), of which 71 were males and 34 were females, and 73 respondents were hunters (12.6\%) with 63 males and 10 females. 519 respondents declared to practice at least one outdoor activity in the Pyrenees (90.0\%) like trekking or skiing.

\section{3. $P C A$ results}

\subsubsection{Opinion on bear presence}

Axis 1 explained $87.2 \%$ of the total variance and the four items of this section of the questionnaire were all positively correlated to this axis (Table A.3), ranging from 0.88 to 0.96 . Because the answers to all four items scaled from strongly opposing bear presence to strongly supporting bear presence, we viewed this component as reflecting the "Opinion on bear presence".

\subsubsection{Bear conservation and management}

Axis 1 explained $68.2 \%$ of the total variance, while Axis 2 explained $8.0 \%$ and Axis 3, 7.5\% (Table A.3). Because none of the 15 items were correlated with Axis 2, we retained only Axes 1 and 3. Items cons 1 to cons8 (importance of bear presence in various areas of the Pyrenees) and cons10 (total protection of the bears in the Pyrenees) were strongly and positively correlated to Axis 1, while items cons 13 to cons 15 (elimination of bears) were negatively correlated to it (Table A.3). Axis 1 was therefore interpreted as the "Opinion on bear conservation". Item cons11 (there should be the possibility to move a bear somewhere else in the Pyrenees if its behavior is problematic) was strongly correlated with Axis 3, which led us to view this axis as the "Opinion on management through bear relocations".

\subsubsection{Bears and hunting activities}

Axis 1 explaining $55.4 \%$ of the variance and Axis 2 explaining $15.7 \%$ (Table A.3) were retained. Items hunt1 to hunt 4 and hunt6, all reflecting the perceived influence of bears on hunting through its impact on wild game, or on hunters themselves, were strongly correlated with Axis 1 (Table A.3). This axis was therefore interpreted as the "Perceived negative impact of bears on hunting". Item hunt5 (possible influence of bears as natural regulators of wild ungulate populations) was strongly correlated to Axis 3, and was therefore viewed as the "Perceived ecosystemic role of bears on wild ungulates".

\subsubsection{Bears and pastoralism}

Axis 1 explained a large proportion of the total variance, and consisted mainly of items pasto1 to pasto5 and pasto7 (Table A.3), which led us to view this axis as the "perceived negative impact of bears on pastoralism". Axis 2 was also retained, and mainly corresponded to item pasto6 that was related to "Prioritizing bear conservation vs. livestock breeding". 


\subsubsection{Bears and tourism}

We kept Axis 1 only (Table A.3), which had a strong correlation with items tour 2 and tour4, and a strong opposite one with tour 1 and tour3 that contained opposite statements. This axis was interpreted as the "Perceived bear influence on tourism".

\subsection{Multiple linear regression of PCA axes on socio-demographic variables}

We focused our analysis on the first axis of the five PCAs, because it explained most of the global variance in every case. The variables and their influence on attitude are shown in Table 2 when considered as main factors in the regression, while their interactions and their influence on attitude are shown in Fig. 2. For clarity, we report the results for the first PCA - opinion on bear presence - and refer the reader to Appendix A for the four other PCAs that led to similar results (Figs. A.1 to A.4).

Seven variables with significant effects were retained in the topperforming regression model for the first axis of all PCAs: Age (Age), County (County), Place of Birth (Birthp), Scientific knowledge of bear ecology (Knowl), Being a livestock breeder (Breed), Being a hunter (Hunt) and Having suffered damage from bears (Damage). Aside from the spatial variables County and Birthplace that are detailed below, negative attitudes were associated with older age, low scientific knowledge of bear ecology, being a livestock breeder or a hunter, and having suffered damage from bears. Positive attitudes were associated with younger age, high scientific knowledge of bear ecology, being neither a livestock breeder nor a hunter, and not having suffered damage from bears (Table 2, Fig. 2).

The fact that the two variables Place of birth and County of residence were significant showed that there was spatial heterogeneity in the attitude towards bears. People born in Pyrenean counties displayed a more negative attitude towards bears than people born outside of the Pyrenees (Fig. 2B). Similar patterns were observed for the variable "County of residence" (Fig. 2A): residents of AR and especially HP displayed the most negative attitude towards bears, while residents of HG and PA displayed positive attitudes. It should be noted that HG was the only county where older individuals displayed a more positive attitude towards bear presence than younger individuals. Residents of counties AU and PO displayed intermediary attitudes, but the low number of answers in PO made it difficult to draw any strong conclusion in their case.
We found that the difference in attitude between people born in the Pyrenees and people born outside of the Pyrenees was stronger among livestock breeders than in the rest of the population (Fig. 2B). Our study also highlighted an attitude change among the newest generations of livestock breeders, with younger livestock breeders having more relaxed attitudes than older ones (Fig. 2C). Age seems to have less influence on the attitude of livestock breeders than it had on non-livestock breeders.

County of residence explained the largest amount of variance in all five models (mean $\eta^{2}=22.46 \pm 5.43$ ), higher than the Age $\times$ County interaction (mean $\eta^{2}=8.28 \pm 1.16$ ) or the Age parameter (mean $\eta^{2}=5.05 \pm 2.23$ ). Place of birth explained a medium amount of variance among all variables (mean $\eta^{2}=8.53 \pm 2.97$ ), lower than pastoralism (mean $\eta^{2}=11.28 \pm 6.37$ ) but higher than hunting practice (mean $\eta^{2}=5.72 \pm 2.71$ ). Overall, both space-specific variables strongly contributed to the attitudinal range (Fig. A.5).

\section{Discussion}

\subsection{Spatial heterogeneity in attitudes}

\subsubsection{County of residence}

Our results show a clear influence of the county of residence on the attitude towards bears. The neutral attitudes in counties AU and PO can be explained by two factors: (i) the lack of bears on their territories in the last few years, and the fact that there were never more than a few bears on their territory since 1999, unlike AR or HG, and (ii) the fact that those two counties also contained wolves, which are usually seen as a much bigger threat to livestock than bears (Bobbé, 2002; Benhammou, 2007; Lescureux and Linnell, 2010).

The positive opinion of HG can be compared with the neutral-tonegative opinion of $A R$, because these counties are located next to each other (Fig. 1) and share the same bear population (Central-Eastern population). Factors other than bear density might explain differences in attitude, because the density of the bear population is similar in both counties. First, bears occupy a larger area in AR than in HG. Pastoralism also constitutes a larger part of the local economy in AR and bears cause more damages in AR than in HG (DREAL, 2015). These results also further reveal the heterogeneity of rural populations (Sponarski et al., 2013).

PA and HP are demographically similar and are both home to the same number of bears - two. PA, which has a positive attitude towards

Table 2

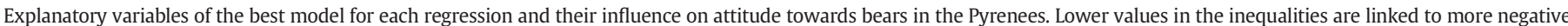

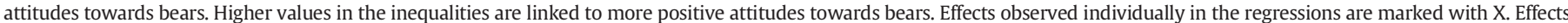

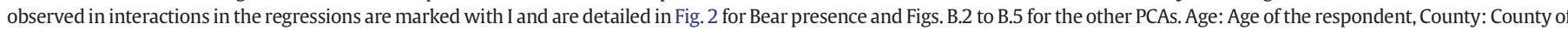

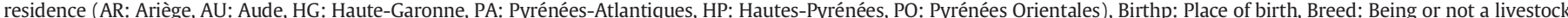

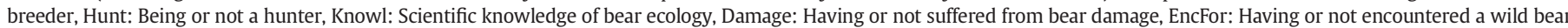

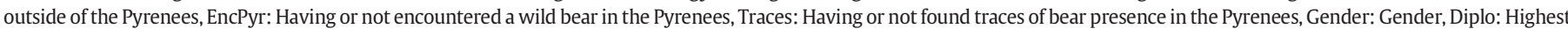
diploma, Resid: Being a primary or secondary resident, Zoo: Having or not seen a bear in a zoo. Bolded: parameters retained in all five PCAs.

\begin{tabular}{|c|c|c|c|c|c|c|}
\hline Variable & Observed effect & $\begin{array}{l}\text { Bear } \\
\text { presence }\end{array}$ & $\begin{array}{l}\text { Bear conservation and } \\
\text { management }\end{array}$ & $\begin{array}{l}\text { Bears and } \\
\text { hunting }\end{array}$ & $\begin{array}{l}\text { Bears and } \\
\text { pastoralism }\end{array}$ & $\begin{array}{l}\text { Bears and } \\
\text { tourism }\end{array}$ \\
\hline Age & Older $<$ Younger & I & I & $\mathrm{X}$ & I & I \\
\hline County & $\mathrm{HP}=\mathrm{AR}<\mathrm{AU}<0<\mathrm{PO}<\mathrm{PA}<\mathrm{HG}$ & I & I & $\mathrm{X}$ & I & I \\
\hline Birthp & Born in the Pyrenees $<$ Born outside of the Pyrenees & I & I & I & I & I \\
\hline Breed & Livestock breeder $<$ Non Livestock breeder & $\mathrm{I}$ & $\mathrm{I}$ & I & I & I \\
\hline Hunt & Hunter $<$ Non hunter & $\mathrm{X}$ & $\mathrm{X}$ & $\mathrm{X}$ & $\mathrm{X}$ & $\mathrm{X}$ \\
\hline Knowl & Low knowledge of bear ecology $<$ High knowledge of bear ecology & & $\mathrm{X}$ & $\mathrm{X}$ & $\mathrm{X}$ & $\mathrm{X}$ \\
\hline Damage & Damage suffered $<$ No damage suffered & $\mathrm{I}$ & $\mathrm{I}$ & I & I & $\mathrm{I}$ \\
\hline EncFor & $\begin{array}{l}\text { No wild bear encounter outside of the Pyrenees }<\text { Wild bear encounter outside of the } \\
\text { Pyrenees }\end{array}$ & $\mathrm{X}$ & $\mathrm{X}$ & & $\mathrm{X}$ & \\
\hline EncPyr & Encounter with a wild bear in the Pyrenees $<$ No encounter with wild bears in the Pyrenees & $\mathrm{X}$ & $\mathrm{X}$ & & & $\mathrm{X}$ \\
\hline Traces & Did not find traces of bear presence $<$ Found traces of bear presence & & & $\mathrm{X}$ & & $\mathrm{X}$ \\
\hline Gender & Female $<$ Male & & & $\mathrm{X}$ & & $\mathrm{X}$ \\
\hline Diplo & Shorter studies $<$ Longer studies & & & $\mathrm{X}$ & $\mathrm{X}$ & \\
\hline Resid & Being a primary resident of the Pyrenees $<$ Being a secondary resident of the Pyrenees & $\mathrm{X}$ & & & & $\mathrm{X}$ \\
\hline Zoo & Never saw a bear in a zoo $<$ Saw a bear in a zoo & & & $\mathrm{X}$ & $X$ & \\
\hline
\end{tabular}


A

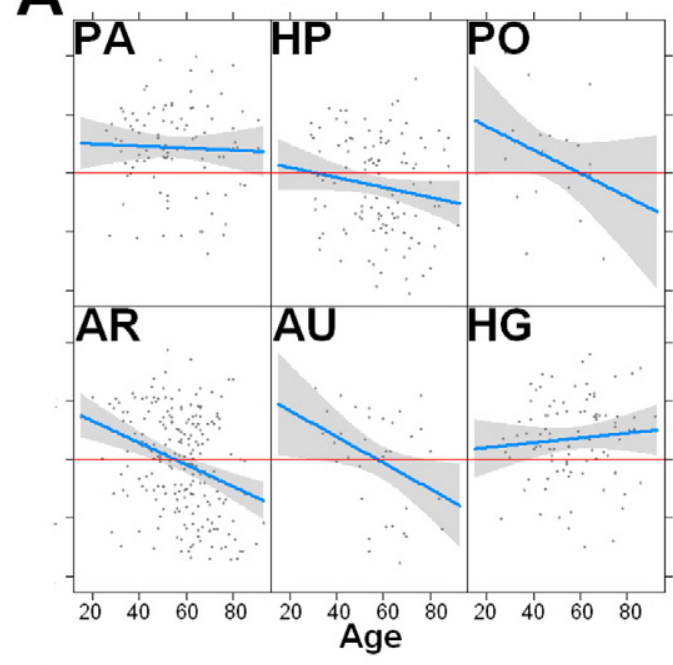

C

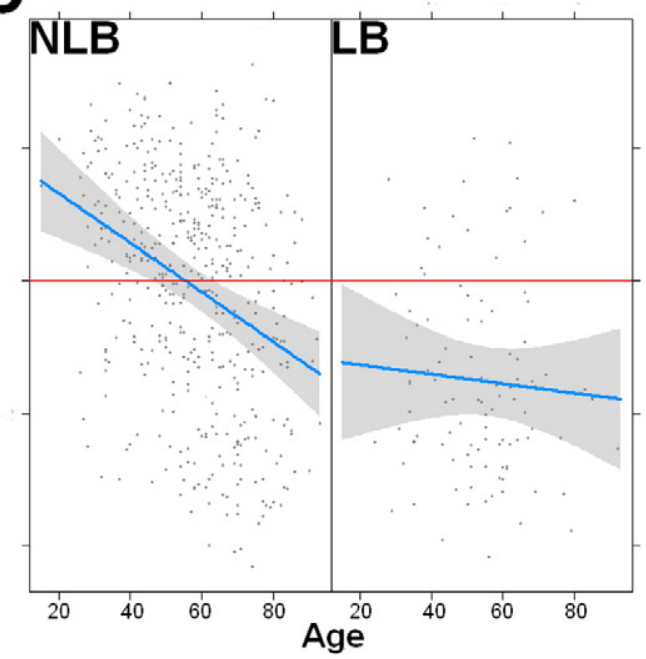

B

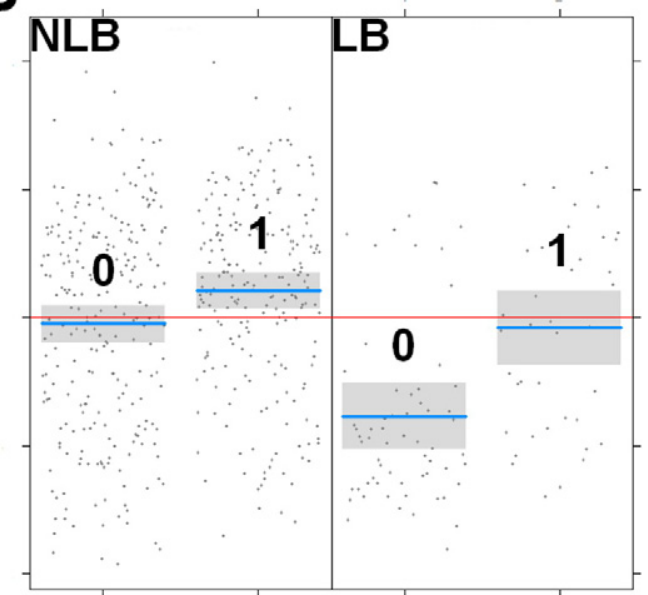

$0=$ Born in the Pyrenees

$1=$ Born outside of the Pyrenees

D

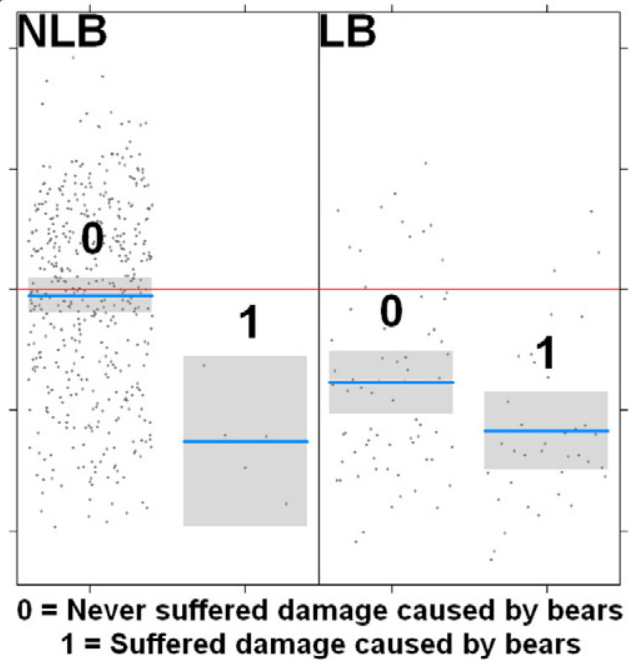

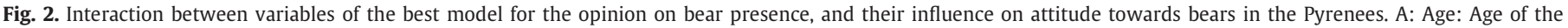

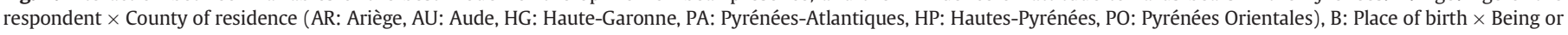

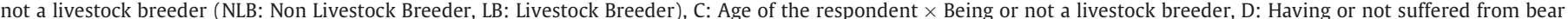

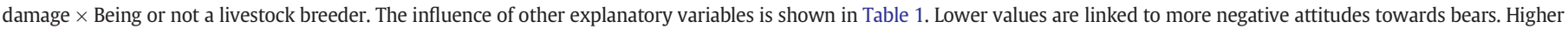

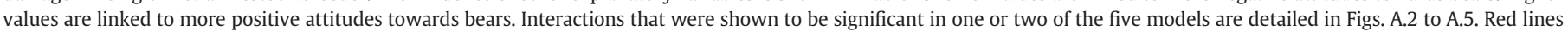
indicate a neutral opinion. (For interpretation of the references to color in this figure legend, the reader is referred to the web version of this article.)

bear, has had a continuous bear presence, and was home to Cannelle, the last female of the Pyrenean bear strain, killed by a hunter in 2004, which led to a positive perception of this particular bear by the locals. Meanwhile HP, which has a comparatively negative attitude towards bears, saw bears returning in 2001 after a reintroduction in HG. The sole individual that was reintroduced here in 2006, Francka, caused a lot of damage to sheep flocks until her death in 2007 (Camarra et al., 2007). The difference in perception between Cannelle and Francka may explain why bear presence is seen as a major nuisance in HP, while in PA it is seen as a minor issue and confirms the importance of individual bears, both in their behavior and their appropriation by locals (Fagen and Fagen, 1996; Linnell et al., 1999, Lescureux et al., 2011). The recent co-presence in HP may also be linked to more negative attitudes towards large carnivores (Zimmermann et al., 2001), especially when compared with the continuous presence in PA. The same comparison can be made to explain the difference between $H G$ and $A R$, because all reintroductions took place in HG, yet many bears moved to AR.

\subsubsection{Place of birth}

The other spatial parameter that influences attitudes was the place of birth of the respondent, with people born in the Pyrenees exhibiting a more negative attitude towards bear presence than people born outside of the Pyrenean counties. Following the assumption that residents who were born in the Pyrenees are more likely to also have grown up there than those who were born outside of the Pyrenees, this observation might suggest that besides residence, the place of socialization is important in human relationships with the environment (HuddartKennedy et al., 2009) and in this case probably plays a role in the development of attitudes towards large carnivores. It further illustrates the heterogeneity of rural populations, and the impossibility to consider them as a block of people sharing similar perceptions.

\subsubsection{Spatial parameters and livestock breeding}

We highlighted the strong influence of place of birth and the moderate influence of age on the attitudes of livestock breeders. Beyond 
possible difference in the general perception of the environment, both can be linked to the duration of exposure to the conflict (livestock breeders born outside of the Pyrenees are more likely to have been exposed later in life to the conflict compared to livestock breeders born in the Pyrenees), and may suggest that longer exposure to the conflict leads to more ingrained and negative attitudes (Treves et al., 2013). This pattern also emerged in a parallel qualitative study in which local stakeholders of AR and HG were interviewed (Borelli-Massines, unpublished results). Generation turnover may have an influence on general attitudes in the future towards bears as well as on future management decisions, although a longitudinal study would be necessary to assess its effect over time (Williams et al., 2002; Majić and Bath, 2010).

\subsection{Control parameters}

Control parameters that we included in our analysis had already been investigated (Kaczensky et al., 2004; Bath et al., 2008; Thornton and Quinn, 2009; Majić and Bath, 2010; Majić et al., 2011; Glikman et al., 2012; Gore and Kahler, 2012; Gangaas et al., 2013; Sponarski et al., 2013). As expected, age, scientific knowledge of the ecology of bears and damage suffered, as well as being a livestock breeder proved to have a significant influence on attitude towards bears (Williams et al., 2002; Ericsson and Heberlein, 2003; Kaczensky et al., 2004; Kleiven et al., 2004; Majić and Bath, 2010). However, gender seemed to have a minor effect only on the attitude if it had any effect at all, while it has been identified as a major driver of attitudes elsewhere (Bath et al., 2008; Gore and Kahler, 2012). One possible explanation is that fear is a usual driver explaining the male/female difference in attitude towards predators (Bath et al., 2008; Zimmermann et al., 2001), but our questionnaire did not include any item related to fear of bears. Hunters have varying attitudes towards large predators: sometimes not different from the rest of the population (Bath et al., 2008; Majić et al., 2011), and sometimes more negative (Ericsson and Heberlein, 2003). In the Pyrenees, hunters tend to have more negative attitudes than the rest of the population. Even though no hunting restrictions linked to bear presence exist, the possibility of their appearance might explain this negative attitude (Borelli-Massines, unpublished data). We also observed that signs of bear presence and encounters with wild bears outside of the Pyrenees were associated with positive attitudes towards bears. The former may be associated with a scientific knowledge of bears' ecology, which can be linked to positive attitudes (Glikman et al., 2012): bears are shy animals, and the detection and identification of bear signs require a good understanding of their biology. However, detailed experience-based knowledge (Lescureux et al., 2011) or familiarity (Reimer et al., 2014) with the bears was not investigated in this study, neither was the extent to which the species' behavior and ecology might influence attitudes (Lescureux and Linnell, 2010).

Two parameters were not found relevant to estimate the attitude of respondents, while we expected otherwise: living in a rural or urban area (Gangaas et al., 2013), and being a primary or secondary resident of the Pyrenees. The low population density in the Pyrenees, and the lack of very large cities in the study area (the largest being Pamiers, AR, with 15,500 inhabitants) can explain the lack of significant differences between residents of urban and rural areas. However, we expected to see a difference between primary and secondary residents, because secondary residents typically spend most of the year farther away from bear territories, and distance to predators has been proposed to explain attitudes (Karlsson and Sjöström, 2007).

\subsection{Return rate and survey sample}

The return rate of properly filled questionnaires reached $16.2 \%$, which was lower than in other studies (Kaczensky et al., 2004; Majić and Bath, 2010). The independence between return rate and county of residence, which was the one parameter we controlled for during the survey, allowed us to assess possible spatial effects on attitude towards bears. The biased gender-ratio can be partly explained by the targeting of livestock breeders and hunters, both social groups that include more men than women (Parmentier, 2014). People under the age of 30 were under-represented in our sample, presumably because many in that age category are students and live in larger cities outside of the study area. It cannot be determined whether the proportion of people born in one of the six Pyrenean counties was representative of the population, because there is no available data on the birthplace of residents of each county. We combined mail questionnaire and interviews in our study to assess the attitudes of members of the general public (Treves et al., 2015) as well as local stakeholders, which can yield insights relevant for the management of conservation conflicts (Redpath et al., 2013).

\section{Conclusion}

Even if bear territories do not match administrative borders, ignoring local human spatial variables when accounting for factors that influence the attitude of the Pyrenees inhabitants may lead to the loss of important information when designing future management plans for the brown bear population. Differences of attitude between counties are harder to understand than most social parameters such as age or gender, because local history, cultural singularities, economics and politics have a strong influence on human relationships with animals (Knight, 2000; Lescureux, 2006; Benhammou, 2007; Lescureux and Linnell, 2013). Nonetheless, spatial heterogeneity in sociodemographic factors should not be ignored, because the large home range size of brown bears (Quenette et al., 2001; Dahle and Swenson, 2003) implies that the population, no matter how small, will cover multiple settlements and other administrative units. Moreover, accounting for spatial heterogeneity allows reducing the influence of extreme attitudes in studies by revealing the spatial configuration of the most vivid supporters or opponents to a predator population. We expect that the inclusion of small-scale spatial variables in future sociological studies of human-wildlife conflicts may lead to an improvement in the understanding of these conflicts.

Understanding spatial variation in attitudes towards wildlife populations can have a twofold effect. First, it helps to identify the areas where the attitudes are the most negative, where any conservation decision strengthening the population is guaranteed to increase the intensity of the conflict. It might also identify areas with more positive attitudes towards the animals, even though it should not be considered as a way to guarantee the success of a relocation or reintroduction. A spatial analysis will not be able to predict the consequences of an important management decision on attitudes, and as such should not be considered as the solution to avoid the aggravation of an existing conflict. It is a prerequisite with qualitative sociological studies in situations where relocations or reintroductions are considered important conservation and management tools.

\section{Acknowledgments}

This study was partly funded by CNRS (InSHS) through La Mission pour l'Interdisciplinarité and the Société Française d'Ecologie. We warmly thank Sandra Laugier for supporting our project, as well as Alistair Bath for his input in the design of the sampling protocol and Mathias Guérin for his sharp answers to our vague questions about the legality of our questionnaire. We are grateful to the volunteers of the Brown Bear Network and the ONCFS Bear Team for collecting and sharing precious data and knowledge on the Pyrenean brown bears. We also thank Jean-Marie Laureys for the mail survey logistics, and Laetitia, Anna, Anne-Sophie, Rachel, Arzhela, Anne, Nathalie, Gaïa, Carole, Sylvia, Gabriel-the-crazy-stamper, Rémi and Gilles for their help in preparing the 3000 envelopes. Guillaume Chapron, Andrew Derocher and the associate editor greatly help in improving a previous 
version of the manuscript, as well as Richard Bischof who kindly corrected our English and made several constructive comments.

\section{Appendix A. Supplementary data}

Supplementary data to this article can be found online at http://dx. doi.org/10.1016/j.biocon.2016.02.027.

\section{References}

Bath, A.J., et al., 2008. From a human dimensions perspective, the unknown large Carnivore: public attitudes toward Eurasian Lynx in Poland. Hum. Dimens. Wildl. 13, $31-46$.

Benhammou, F., 2007. Crier au loup pour avoir la peau de l'ours - Une géopolitique locale de l'environnement à travers la gestion et la conservation des grands prédateurs en France PhD Environmental Sciences, ENGREF Paris (665p).

Bobbé, S., 2002. L'ours et le loup, Essai d'anthropologie symbolique. Editions de la Maison des sciences de l'homme, Paris.

Burnham, K.P., Anderson, D.R., 2002. Model Selection and Multimodel Inference: A Practical Information-theoretic Approach. second ed. Springer, New York.

Camarra, J.J., et al., 2007. Rapport sur le suivi de l'ours Francka. ONCFS (42p).

Camarra, J.J., et al., 2015. Suivi de l'ours brun dans les Pyrénées françaises, Rapport annuel, Année 2014. ONCFS (58p).

Chapron, C., et al., 2009. Diagnosing mechanisms of decline and planning for recovery of an endangered Brown Bear oopulation. PLoS One 4 (10).

Chapron, C., et al., 2014. Recovery of large carnivores in Europe's modern humandominated landscapes. Science 346, 1517-1519.

Cohen, J., 1973. Eta-squared and partial eta-squared in fixed factor ANOVA designs. Educ. Psychol. Meas. 33, 107-112.

Dahle, B., Swenson, J.E., 2003. Seasonal range size in relation to reproductive strategies in brown bears. J. Anim. Ecol. 72, 660-667.

Dillman, D.A., et al., 2014. Internet, Phone, Mail and Mixed-Mode Surveys - The Tailored Design Method. fourth ed. Wiley, Hoboken.

Dorresteijn, I., et al., 2014. Human-carnivore coexistence in a traditional rural landscape. Landsc. Ecol. 29, 1145-1155.

DREAL, 2015. Midi-Pyrénées. http://www.midi-pyrenees.developpement-durable.gouv fr/ours-brun-r3054.html (last accessed July 2015).

Dressel, S., et al., 2015. A meta-analysis of studies on attitudes toward bears and wolves across Europe 1976-2012. Conserv. Biol. 29, 565-574.

European Union, 1992. Council Directive 92/43/EEC of 21 May 1992 on the conservation of natural habitats and of wild fauna and flora. http://eur-lex.europa.eu/legalcontent/EN/TXT/?uri=CELEX:31992L0043.

Ericsson, G., Heberlein, T.A., 2003. Attitudes of hunters, locals, and the general public in Sweden now that the wolves are back. Biol. Conserv. 111, 149-159.

Fagen, R., Fagen, J.M., 1996. Individual distinctiveness in brown Bears, Ursus arctos L. Ethology 102 (2), 212-226.

Gangaas, K.E., et al., 2013. Geo-spatial aspects of acceptance of illegal hunting of large carnivores in Scandinavia. PLoS One 8 (7).

Glikman, J.A., et al., 2012. Residents' support for wolf and bear conservation: the moderating influence of knowledge. Eur. J. Wildl. Res. 58, 295-302.

Gore, M.L., Kahler, J.S., 2012. Gendered risk perceptions associated with human-wildlife conflict: implications for participatory conservation. PLoS One 7 (3)

Huddart-Kennedy, E., et al., 2009. Rural-urban differences in environmental concern in Canada. Rural. Sociol. 74 (3), 309-329.

INSEE, 2014. Bilan démographique 2014. http://www.insee.fr/fr/themes/detail.asp?ref id=bilan-demo (last accessed July 2015).

Kaczensky, P., et al., 2004. Public attitudes towards brown bears (Ursus arctos) in Slovenia. Biol. Conserv. 118, 661-674.

Karlsson, J., Sjöström, M., 2007. Human attitudes towards wolves, a matter of distance. Biol. Conserv. 137, 610-616.
Kleiven, J., et al., 2004. Factors influencing the social acceptability of large carnivore behaviours. Biodivers. Conserv. 13, 1647-1658.

Knight, J., 2000. Natural Enemies - People-Wildlife Conflicts in Anthropological Perspective. Routledge, London.

Lescureux, N., 2006. Towards the necessity of a new interactive approach integrating ethnology, ecology and ethology in the study of the relationship between Kirghiz livestock breeders and wolves. Soc. Sci. Inf. 45, 463-478.

Lescureux, N., Linnell, J.D.C., 2010. Knowledge and perceptions of Macedonian hunters and Herders: the influence of species specific ecology of Bears, Wolves, and Lynx,. Hum. Ecol. 38, 389-399.

Lescureux, N., Linnell, J.D.C., 2013. The effect of rapid social changes during postcommunist transition on perceptions of the human-wolf relationships in Macedonia and Kyrgyzstan. Pastoralism 3, 4

Lescureux, N., et al., 2011. The king of the forest. Local knowledge about European brown bears and implications for its conservation in contemporary Western Macedonia,. Conserv. Soc. 9, 189-201.

Linnell, J.D.C., et al., 1999. Large carnivores that kill livestock: do problem individuals exist? Wildl. Soc. Bull. 27, 698-705.

Majić, A., 2007. Human dimensions in wolf management in Croatia: understanding public attitudes toward wolves over time and space. Thesis, Memorial University of Newfoundland. Canada, St. John's.

Majić, A., Bath, A.J., 2010. Changes of attitudes toward wolves in Croatia. Biol. Conserv. $143,255-260$

Majić, A., et al., 2011. Dynamics of public attitudes toward bears and the role of bear hunting in Croatia. Biol. Conserv. 144, 3018-3027.

Mermet, L., 1998. L'Analyse Stratégique de la Gestion Environnementale illustrée par les tribulations d'un noyau relictuel de population d'ours bruns dans les Pyrenees occidentals françaises. RGTE/ENGREF, Paris (484p).

Mermet, L., Benhammou, F., 2005. Prolonger l'inaction environnementale dans un monde familier: la fabrication stratégique de l'incertitude sur les ours du Béarn. Econ. Polit. 31, 121-136

Parmentier, M., 2014. Les exploitants et entrepreneurs agricoles en 2012. http://www. msa.fr/lfr/documents/98830/9488292/ Les+exploitants+et+entrepreneurs + agricoles+en+2012.pdf (Last accessed July 2015)

Quenette, P.Y, et al., 2001. Preliminary results of the first transplantation of brown bears in the French Pyrenees. Ursus 12, 115-120.

$\mathrm{R}$ Core Team, 2013. R: A language and environment for statistical computing. R Foundation for Statistical Computing, Vienna, Austria.

Redpath, S.M., et al., 2013. Understanding and managing conservation conflicts. Trends Ecol. Evol. 28, 100-109.

Reimer, A., et al., 2014. The impact of information and familiarity on public attitudes toward the eastern hellbender. Anim. Conserv. 17, 235-243.

Sponarski, C.C., et al., 2013. Heterogeneity among rural resident attitudes toward wolves. Hum. Dimens. Wildl. 18, 239-248.

Thornton, C., Quinn, M.S., 2009. Coexisting with cougars: public perceptions, attitudes, and awareness of cougars on the urban-rural fringe of Calgary, Alberta, Canada. Hum.-Wildl. Confl. 3, 282-295.

Treves, A., Karanth, K.U., 2003. Human-carnivore conflict and perspectives on carnivore management worldwide. Conserv. Biol. 17, 1491-1499.

Treves, A., et al., 2013. Longitudinal analysis of attitudes toward wolves. Conserv. Biol. 27 (2), 315-323.

Treves, A., et al., 2015. Predators and the public trust. Biol. Rev. http://dx.doi.org/10.1111/ brv.12227.

van Belle, G., et al., 2004. Biostatistics: A Methodology For The Health Sciences. second ed. Wiley, Hoboken.

Williams, C.K., et al., 2002. A quantitative summary of attitudes toward wolves and their reintroduction (1972-2000). Wildl. Soc. Bull. 30, 575-584.

Zimmermann, B., et al., 2001. Human-carnivore interactions in Norway: how does the reappearance of large carnivores affect people's attitudes and levels of fear? For. Snow Landsc. 76, 137-153. 